ABCDDV/1243

$A B C D$ Arq Bras Cir Dig Letter to the Editor 2016;29(3):211-212

DOI: /10.1590/0102-6720201600030019

\section{GASTROINTESTINAL SCHWANNOMA: CASE REPORT}

\author{
Schwannoma gastrointestinal: relato de caso
}

Rafael Dienstmann Dutra VILA, Marlise Mello Cerato MICHAELSEN, Karine Sabrina BONAMIGO, Nilo Luiz CERATO, Valério Celso Madruga de GARCIA, Patrícia da Silva PASSOS, Adriano Calcagnotto GARCIA

From the Serviço de Coloproctologia, Hospital Ernesto Dornelles (Coloproctology Service, Hospital Ernesto Dornelles), Porto Alegre, RS, Brazil

HEADINGS - Gastrointestinal schwannoma. Mesenquimal tumor. Colorectal tumor.

DESCRITORES - Schwannoma gastrointestinal. Tumor mesenquimal. Tumor colorretal.

Financial source: none

Correspondence:

Adriano Calcagnotto Garcia

Conflicts of interest: none

Received for publication: 25/03/2015

his is an open-access article distributed under the terms of the Creative Commons Attribution License.

INTRODUCTION

S chwannoma is a benign, neurogenic, slow-growing neoplasia, originated from Schwann cells, which are responsible by the myeline sheath on the peripheral nerves. This type of tumor is found more frequently on the central and peripheral nervous system and rarely occurs on the gastrointestinal tract ${ }^{1,2,4,5,6,8,10}$. Along with leiomyoma, leiomyossarcoma, gastrointestinal stromal tumor (GIST) and others, it makes part of the mesenchymal gastrointestinal tumors group $2,5,6,10$.

\section{CASE REPORT}

Female, 74 years old, presented on the emergency room with a chief complaint of abdominal pain, nauseas, vomiting, prostration and dizziness with one week of evolution. She reported past history of diverticulitis and denied weight loss, hematoquezia or previous abdominal surgeries. During the physical examination, she complained of pain on deep upper abdominal palpation, although no abnormal mass could be detected. Proctologic examination and laboratory exams showed no abnormalities.

Abdominal ultrassonography showed a nodular solid heterogenic type image on the left flank, with $6.1 \times 5.6 \times 4.3 \mathrm{~cm}$. Investigation with contrasted computed tomography detected an delimited intramural lesion on the transverse colon, without invasion of surrounding organs (Figure 1).

Colonoscopy, with exploration until the cecum, showed not only sigmoidal diverticulus, but also an intraluminal bulging on the topography of distal transverse colon, with adjacent normal aspect mucosa, suggesting extrinsic mass growth and lumen compression. Since the research for metastatic lesions was negative, extended left colectomy was performed, with ressection of $18 \mathrm{~cm}$ intestinal segment, containing a $5.6 \times 5.0 \times 4.8 \mathrm{~cm}$ mass, located on the transverse colon, beside the splenic angle. The pacient had a satisfatory evolution, leaving hospital on the $6^{\text {th }}$ postoperative day.

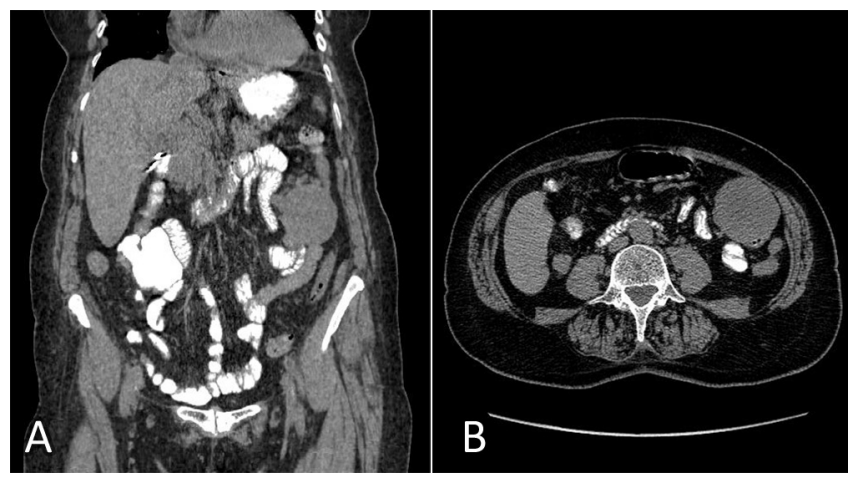

FIGURE 1 - Splenic angle mass: A) CT coronal slice; B) TC axial slice (distal transverse colon)

The anatomopathologic analysis have highlighted a fusiform cell mesenchymal lesion, extending from colon submucosa until its subserous layer, with moderate cell nucleus atypia and two mitosis per 50 high-power fields, without evidence of hemorrhage or necrosis.

Immunohistochemical research showed positive results for kit gene products (C-kit/CD117) and for glial fibrillary acidic protein (GFAP) and S-100 protein. The results for hematopoietic cells antigene (CD34), desmine and smooth muscle actin (CD117) were negative. This profile was compatible with a gastrointestinal tract schwannoma diagnosis.

\section{DISCUSSION}

Schwannoma represents $0,2-1 \%$ of all gastrointestinal tract tumors, occuring more frequently on the stomach and rarely on colon and esophagus , $, 2,4,5,6,9,10$. The mean age of incidence is around 50-60 years old, with equal gender prevalence ${ }^{2,4,7,8}$. It usually manifests itself by abdominal pain, constipation, gastrointestinal bleeding, weight loss, but sometimes it shows no significant syntoms $\mathrm{s}^{2,4,6,10}$. It is classified as a mesenchymal gastrointestinal tumor ${ }^{6}$.

The initial evaluation is made by computed tomography or nuclear magnetic resonance (NMR) to determine location, size, density of the lesion and attempt to identify metastasis ${ }^{2}$. Colonoscopy usually shows unharmed mucosa and an insert image sugesting extrinsic compression of intestinal lumen. However, all mesenchymal tumors have similar colonoscopic image aspect, making it difficult to set an specific diagnosis. In addition, a colonoscopy guided biopsy is not always able to collect sufficient amount of tissue to ensure a correct diagnosis ${ }^{5}$. Thus, anatomopathological and immunohistochemical research of the surgically resected lesion is mandatory ${ }^{4,5}$.

Therefore, in case of dealing with a resectable neoplasia, with high probability of mesenchymal tumor, surgical approach is indicated, with wide margin lesion resection, without necessity of lymphadenectomy, since the risk of metastasis in those cases is very low ${ }^{1,2,4,5,6,9,10}$. Considering the higher prevalence of GIST, the majority of schwannomas is misdiagnosed, until histological and immunohistochemical research and differentiation is concluded ${ }^{4,5}$.Schwannoma presents significant cell pleomorphism, lymphoid follicles, rare mitotic cells and rare necrotic spots. GIST shows high mitotic index, necrotic and hemorragic spots, without lymphoid follicles. Leiomyoma, on the other hand, does not show any of those characteristics ${ }^{2,3,6}$. The most important immunohistochemical markers are CD117, CD34, S-100 protein, GFAP, SMA and desmine. Schwannoma is S-100- and GFAPpositive, but CD117- and SMA-negative. GIST is CD117- and CD34-positive, S-100- and GFAP-negative. Leiomyoma is CD117-, CD34-, S-100- e GFAP-negative. However, the latest is desmine- and SMA-positive, which are negative markers on schwannoma and GIST ${ }^{4,5,6,7}$ (Figure 2). 


\begin{tabular}{|c|c|c|c|}
\hline & Schwannoma & GIST & Leyomioma \\
\hline CD 117 (C-Kit) & Negative & Positive & Negative \\
\hline CD 34 & Negative & Positive & Negative \\
\hline S-100 & Positive & Negative & Negative \\
\hline GFAP* & Positive & Negative & Negative \\
\hline SMA ${ }^{* *}$ & Negative & Negative & Positive \\
\hline Desmine & Negative & Negative & Positive \\
\hline
\end{tabular}

* Glial fibrillary acidic protein; ** Smooth muscle actin

FIGURE 2 - Mesenchymal tumor immunohistochemical profile

The most important mesenchymal tumors prognosis factors, specially for GIST, are tumor size and mitosis index ${ }^{2}$. The less replicative and smaller is the neoplasia, the better is the prognosis. Radio and chemotherapy role in schwannoma remains uncertain; meanwhile, the recommended treatment is wide margin resection, without need of lymphadenectomy, mostly with excellent results ${ }^{5,9}$.

\section{REFERENCES}

1. Almeida MG, Hirschfeld APM, Farinha JCG, Roque MT, Ribeiro FLM, MendonçaPM, VolpianiJA.SchwannomadeReto Associadoà Doençade VonRecklinghausen-RelatodeCaso. RevbrasColoproct,2005;25(1):64-66.

2. Friedman $M$, Nannegari V , Jones $D$, Valerian BT. An Unusual Finding of ColonicSchwannoma.Practical Gastroenterology.2011 December,56-59.

3. Hou YY, Tan YS, Xu JF, Wang XN, Lu SH, JiY, Wang J,ZhuXZ. Schwannoma ofthegastrointestinaltract:aclinicopathological,immunohistochemicaland ultrastructural study of 33 cases. Histopathology.2006 Apr;48(5):536-45.

4. HsuWH, WuIC, Chen Cy, ChiangSL, Chen HW, WuDC.ColonSchwannoma: A Case Report. 2009;20:255-259.

5. Hung HY, Chiang JM, Chen JS, Tang R, Chen TS. Schwannoma of the Colon: Report of Case and Review of the Literature. J Soc Colon Rectal Surgeon (Taiwan) December 2008.

6. Kown MS, Seung SL, Ahn GH. Schwannomas of the gastrointestinal tract: clinicopathological features of 12 cases including a case of esophageal tumor compared with those of gastrointestinal stromal tumors and leiomyomas of the gastrointestinal tract. Pathol Res Pract. 2002;198(9):605-13.

7. Liegl B, Bennett MW, Fletcher CD. Microcystic/reticular schwannoma: a distinct variant with predilection for visceral locations. Am J Surg Pathol. 2008 Jul;32(7):1080-7.

8. Miettinen M, Shekitka KM, Sobin LH. Schwannomas in the colon and rectum: a clinicopathologic and immunohistochemical study of 20 cases. Am J Surg Pathol. 2001 Jul;25(7):846-55.

9. Park KJ, Kim KH, Roh YH, Kim SH, Lee JH, Rha SH, Choi HJ. Isolated primary schwannoma arising on the colon: report of two cases and review of the literature. J Korean Surg Soc. 2011 May;80(5):367-72. Epub 2011 May 6.

10. Xu M. Gastric Schwannoma: a rare Schwann cell tumour of the GI tract. UWOMJ | 80:S1 | Summer 2011.
ABCDDV/1244

ABCD Arq Bras Cir Dig Letter to the Editor

2016;29(3):212-213

DOI: /10.1590/0102-6720201600030020

\section{SELF-EXTERMINATION ATTEMPTED THROUGH THE 128 NAILS INTAKE}

Tentativa de autoextermínio através da ingestão de 128 pregos

Juliana L LUSVARGHI, Marcelo C FATURETO

From the Universidade Federal do Triângulo Mineiro - UFTM, Uberaba, MG, Brazil

HEADINGS - Suicide. Teenager. Nail.

DESCRITORES - Suicídio. Adolescente. Pregos

Correspondence:

Juliana L Lusvarghi

Financial source: none E-mail:jujullusvarghi@hotmail.com; Received for publication: 20/05/2015 mfat@terra.com.br Accepted for publication: 24/05/2016

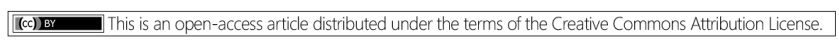
INTRODUCTION population ${ }^{7}$.

According to the World Health Organization, various stress conditions can increase the risk of suicide ${ }^{1}$. Eighty-five percent of patients who ingest foreign body have previous psychiatric illness and $84 \%$ of these patients have had previous intakes ${ }^{5}$.

From ingested foreign bodies $90 \%$ pass spontaneously through the gastrointestinal tract; $10-20 \%$ requires endoscopic removal; and $1 \%$ surgical approach ${ }^{6}$. In the general population, the foreign bodies are more often accidentally ingested such as bones, thorns or fruit stones. Most are housed in the physiological constrictions of the esophagus or abnormal narrowing sites (stenosis, rings or malignant tumors).

Here is presented one case of self-extermination attempt with continuous intake of nails in the course of a year.

CASE REPORT

Teenager of 16 year old was admitted with nails intake history during one year claiming attempt to self-extermination after constant arguments with his father and continuous nails intake. The parents were scavengers and had woodwork in which the patient had free access to the ingested material. Two days of admission he had epigastric pain, vomiting, and an episode of blackened stools. Physical examination showed good general condition, no collaborative, pallid $(1+/ 4+)$, emaciated, heart beat $105 \mathrm{bpm}$, blood pressure of $120 \times 80 \mathrm{mmHg}$, flat and flaccid abdomen, painful to deep palpation of epigastrium and no sudden pain to decompression. A large number of nails in the left iliac fossa was seen in abdominal radiograph (Figure 1); blood count was with leukocytosis and left shift. 